\title{
Overtourism at Baikal: Problems and Ways of Addressing Them
}

\author{
A. Yu. Aleksandrova ${ }^{a, *}$, S. N. Bobylev ${ }^{a, * *}$, S. V. Solovyeva ${ }^{a, * * *}$, and I. Yu. Khovavko ${ }^{a, * * * *}$ \\ ${ }^{a}$ Moscow State University, Moscow, 119899 Russia \\ *e-mail:analexan@mail.ru \\ **e-mail: snbobylev@yandex.ru \\ ***e-mail: solovyevasv@gmail.com \\ ****e-mail: irina.hov@rambler.ru
}

Received April 17, 2020; revised October 15, 2020; accepted March 25, 2021

\begin{abstract}
This article examines the socio-economic causes and consequences of a high load on tourist destinations (overtourism) in the Baikal Natural Territory (BNT). An economic analysis is made of the existing tourist flows. The areas of conflict of the interests of tourist business, the local population, authorities of different levels and investors have been identified. This study summarizes the results of field investigations made in a number of districts of Buryatia in order to develop the strategy of sustainable ecologically balanced development of the territory. The technique of informal interviews was used to identify and compare the opinions of different categories of people on the reasons behind the conflict of the interests in the BNT and the methods of settling them. Estimates of the economic benefits from the flow of unorganized tourists in the Baikal region of Buryatia by the method of travel costs have been obtained. It is shown that the policy of restriction on economic activities in the BNT and reliance on mass tourism lead to the degradation of the nature in Bai$\mathrm{kal}$ and do not solve the problems of financial self-sufficiency of the territory. The mass nature of the tourist flow stifles the possibility for full-fledged communication with wildlife and for an educational and comfortable recreation provided that the recreational load on the territory is observed. In addition, super-tourism territories are vulnerable to emergencies (such as epidemics).
\end{abstract}

Keywords: permissible tourist load, sustainable tourism, responsible tourism, overtourism, Lake Baikal

DOI: $10.1134 / \mathrm{S} 1875372821030033$

\section{INTRODUCTION}

This article was written at the height of the COVID-19 pandemic, when all tourism activities in the world were paralyzed. Nevertheless, the authors believe that the problem of exceeding the maximum permissible loads in popular tourist centers has not lost its relevance. Moreover, its aggravation is expected as early as in the short term, after the lifting of quarantines and growth of the deferred tourist demand.

One of the challenges of our time is overtourism (overtourism is excessive and superfluous tourism) as a result of the excessive popularity of tourist sites. Today, the threat of overtourism hangs over the greatest lake in the world: Baikal. The UNESCO Convention On the Protection of the World Cultural and Natural Heritage in 1999 included Baikal in the UNESCO World Heritage List, which imposed certain obligations on the Russian Federation to preserve the lake. To implement the requirements of the international status of Baikal in Russia, a number of legislative acts were adopted, which significantly changed the socioeconomic conditions of life of the local population. Three ecological zones were identified on the Baikal Natural Territory (BNT): the central ecological zone
(CEZ), the buffer ecological zone, and the ecological zone of atmospheric influence.

Numerous types of zoning imposed by directives limited the potential of doing business on the BNT, which led to confrontation between local residents and the authorities. Over 40 types of economic activity were prohibited by the CEZ regime, 8 types were prohibited by the regime of the water protection zone, and 5 types were prohibited by the norms of the Forest Code for forests located in water protection zones [1]. In addition, the recent trend towards the commercialization of specially protected natural areas is also characteristic of the BNT. Despite the fragility of the Baikal ecosystems and the lack of the necessary tourist infrastructure for mass recreation, an active advertising campaign has begun in the country to attract tourists at Baikal. This has led to an increase in the flow of Russian and foreign tourists by several times.

The goal of the study was to assess the impact of tourism on the situation in the BNT. For this purpose, the study analyzed the socio-economic reasons and consequences of the high load on tourist destinations (overtourism); carried out an economic analysis of the existing tourist flows on the BNT; and identified areas 
of conflict of interests of the tourist business, local population, authorities of different levels and investors. The results presented in this article were based on field studies carried out from July 11-17, 2018 in Ulan-Ude, in the Pribaikalskii, Barguzinskii, and Tarbagataiskii districts of the Republic of Buryatia, as well as on Olkhon Island.

\section{OVERTOURISM AS A NEW GLOBAL CHALLENGE}

The problem of spatial and temporal unevenness of tourism development and the concentration of tourists in well-known tourist centers during the high season is not new. However, this phenomenon was not always so large-scale and the social conflicts provoked by it were not as deep. Venice, Barcelona, Amsterdam, and Dubrovnik were among the first to face overtourism. It took on the most acute forms in these European cities. For example, from 2003 to 2019, the number of tourist arrivals in Venice doubled, reaching $5.5 \mathrm{mln}$ people in 2019 [2] (while the number of residents in the historical center was 55000 people [3]). Under the onslaught of tourists, the local population is forced to leave the city. Over the past 50 years, the number of Venetians has decreased by $66 \%$ [4]. This process is called the Venetian syndrome [5]. The problems of overtourism are faced not only by urban agglomerations, but also by the countryside, natural objects, beach resorts, national parks, etc. [6-12].

There is still no generally accepted definition of overtourism, but all experts associate this phenomenon with the excess of the maximum capacity in a tourist destination, primarily social capacity [13]. That is, overtourism arises when the hosts and guests feel that there are too many visitors and the quality of life in the area or the quality of impressions is unacceptably deteriorating [14-16].

Overtourism is caused by a complex of reasons, which have been covered in sufficient detail in the literature [14-20]. First of all, it is associated with an unprecedented increase in tourist travel. From 1950 to 2018, international tourist flows increased by 56 times, from $25 \mathrm{mln}$ arrivals to 1.4 bln [19]. Domestic tourists, whose share in many developed countries reaches 75$80 \%$ of the total tourist flow, also contribute to the development of overtourism [21]. The increased mobility of modern society in turn is a consequence of a number of factors. The main one is the increase in the availability of travel products (budget airlines, cheap hostels, and the Airbnb short-term rental system) and the ease of finding, choosing and buying travel products under the conditions of digitalization. New special types of tourism have appeared (event, gastronomic, halal, dark, paranormal tourism, etc.), which have also increased the tourist activity of the population $[22,23]$. Some role has been played by a significant increase in the income of the population in developing countries, in particular in China, and a sharp rise in the middle class there.

The increase in tourist flows is an important, but not the only factor in the emergence of overtourism. The problem is also rooted in effective strategies for promoting tourist destinations and errors in tourism management, which often lead to a tourism bubble $[27,28]$. Until now, the priority of policy in the field of tourism is increasing the economic contribution of tourism through the growth of tourists, and the priority in the tourism business is getting momentary commercial benefits from serving an increasing number of clients [29-31]. The problems of overtourism are aggravated by the disrespectful attitude of many tourists to local communities and the touristization of popular places [24-26]. The destruction of the traditional living environment of the local population results in tourism phobia, that is, rejection and even hatred towards tourists [14, 30, 32, 33]. These phenomena must serve as a warning to the countries that are increasing inbound and domestic tourist flows without thinking about the consequences.

Overtourism leads to various negative consequences. In the environmental sphere, these include pollution of the environment with solid household waste, exhaust gases from tourist transport, noise, degradation of ecosystems and landscapes, and the threat of disappearance of objects of natural and cultural heritage; in the economic sphere, these include rising prices and inflation, speculative transactions with real estate, falling solvency of the local population, increasing costs of utilities, congestion of the transport infrastructure, etc.; in the social sphere, these are the seizure of public spaces by tourists, the transformation of the urban environment with the mass replacement of objects of daily life of residents (for example, shops) with elements of tourist infrastructure (souvenir stalls, cafes, etc.), vandalism, an increase in crime; and loss of the sociocultural identity of the place [23, 34, 35]. Thus, the uncontrolled development of tourism brings more negative consequences than positive effects.

\section{CRITERIA OF OVERTOURISM}

One important question is at what values of tourist flows it is possible to speak of overtourism. Determining the limits of the permissible level of tourism (permissible load and carrying capacity) is a very difficult scientific task. The United Nations World Tourism Organization (UNWTO) defines the capacity as "the maximum number of people who can simultaneously visit a tourist destination without causing destruction of the physical, economic, and sociocultural environment and an unacceptable decrease in the quality of satisfaction of its visitors" [36, p. 7].

There are approaches to determining the permissible load of natural objects, unique objects of cultural heritage, but full-fledged studies on calculating the 
permissible load in areas of large-scale development of mass tourism have not been carried out [37]. In addition, these estimates will vary markedly for different destinations. An understanding has been formed that the social dimension (satisfaction of visitors, tolerance of residents, crime rate, etc.) is becoming of paramount importance along with the environmental and economic dimensions of the permissible load.

The literature shows that sustainable development is such a development in which people want to live on their land [38]. It is the local population that is most capable of ensuring the long-term sustainable use of the territory's resources. The key question is to what extent it manages to maintain control over resources. As the German ecologist J. Radkau rightly noted, "the problem of environmental destruction arises where the local population loses control over its resources and cannot protect them from outsiders" [39, p. 22]. Researchers of overtourism focus their attention on the relationship between the local population and visitors, using the well-known guest-host concept as a methodological basis [40, 41]. These relationships are very multifaceted. Residents play a special role in creating a strong brand for the territory. The hospitality of local residents is one of the signs of the destination's readiness to receive visitors. However, as the number of visitors grows and their ratio to the local population changes not in favor of the latter, the initial positive attitude changes. Under the conditions of overtourism, residents lose contact with the territory where they live. The perception of overtourism by local residents is sometimes manifested as a special case of solastalgia, that is, a person's reaction to the destruction of his usual environment [43]. It is noted that today local residents are more interested in the quality of life than in the direct income generated by the tourism industry [23].

As for the reaction of tourists to the overloading of popular tourist destinations, it is ambiguous and depends on the type of visitors, time, territory and other factors. In any case, the growing anti-tourist sentiment and tourism phobia are the result of a deterioration of mutually beneficial interaction between local residents and tourists.

\section{TOURIST FLOWS}

\section{IN THE BAIKAL NATURAL TERRITORY}

In Soviet times, Lake Baikal was a popular holiday destination. There were many tourist centers of local enterprises, and hiking tourism was developing. Most of the tourist centers of the Baikal region could receive tourists only in summer, providing their guests with minimal amenities. It was emphasized that it was impossible to build large hotels, sanatoriums, and rest homes on Lake Baikal following the example of the Black Sea resorts, since this could harm nature. In the past 2 decades, a course has been taken to promote tourism on Lake Baikal, which was planned by the authorities to provide income for the local population, which fell due to the imposed restrictions on economic activities.

In the opinion of the authorities, an important role in the development of tourism on Lake Baikal was to be played by federal target programs (FTPs) as well as the formation of special economic zones of tourist and recreational type (SEZ TRT) on the BNT. For 20082015 the volume of investments in the SEZ Vorota Baikala (Irkutsk oblast) amounted to $261.6 \mathrm{mln}$ rubles of state budget funds, and investments in the SEZ of the Republic of Buryatia Baikalskaya Gavan' amounted to 4.9 bln rubles [44]. The Vorota Baikala project was closed after inspections by the Accounts Chamber of the Russian Federation, and the Baikalskaya Gavan' project, which did not find sufficient resident investors, was transferred from federal ownership to republican ownership in 2017. According to the data of the Accounts Chamber, budget funds in the amount of 8.4 bln rubles within the framework of the FTP Protection of Lake Baikal and the Socio-economic Development of the Baikal Natural Territory for 2012-2020 were also wasted.

The population is disappointed in the tourism project: for example, only 15 jobs were created during the period of operation of the Baikalskaya Gavan' project. However, the advertisement around the Vorota Baikala and Baikalskaya Gavan' projects gave impetus to the growth of unorganized tourism on Lake Baikal. In 2010-2014, there was an almost two-fold increase in the flow of tourists to Lake Baikal [45]. According to data of the Ministry of Natural Resources of the Russian Federation, in 2015 the number of officially registered tourists alone that visited the Irkutsk oblast and the Republic of Buryatia was 2401.5 thousand people (the number of tourists was more than $1.4 \mathrm{mln}$ people in the Irkutsk oblast and almost $1 \mathrm{mln}$ people in the Republic of Buryatia [44]).

Forty zones of recreational destinations have been developed directly on the shore of Lake Baikal, within the boundaries of the CEZ BNT, where the bulk of accommodation facilities were concentrated, that is, tourist centers, hotels, rest homes, etc. Most of them are confined to shore settlements, where tourism becomes the main source of income for the local population [45]. The studies [45, 46] showed that the growth in the recreational load has an increasingly detrimental effect on the ecological state of the territory. An extremely acute situation has developed in settlements such as Maksimikha, Enkhaluk, Sukhaya, Turka, Gremyachinsk, Goryachinsk, Baikalskiy Priboi, Kultushnaya, Posolskoye, and Dulan, where the ratio of the local population to tourists in the peak season is $1: 5$ and $1: 10$ in some places [47].

The largest flow of tourists is accounted for by the Baikal National Park (BNP). It also includes Olkhon Island, a cult center, a sacred ancestral home of the Buryat people, which has now been turned into a tour- 
Table 1. The number of tourists accommodated in the CAFs of Buryatia and income from tourism in 2016-2019, according to [55-57]

\begin{tabular}{l|r|r|r|r}
\hline \multirow{2}{*}{ Indicator } & \multicolumn{3}{|c}{ Year } \\
\cline { 2 - 5 } & 2016 & 2017 & 2018 & 2019 \\
\hline Total number of tourists, people & 395560 & 407818 & 417584 & 429619 \\
Including & & & & 4981 \\
$\quad$ foreign & 54174 & 52966 & 45516 & 49881 \\
$\quad$ russian & 341386 & 354852 & 372068 & 379738 \\
Income from domestic tourism, thous rubles & 1172442 & 1403930 & 1438312 & 1625608 \\
Income from inbound tourism, thous rubles & 217743 & 201262 & 199965 & 266120 \\
Income from one foreign tourist, rubles & 4019 & 3800 & 4393 & 5335 \\
Income from one Russian tourist, rubles & 3434 & 3956 & 3866 & 4281 \\
\hline
\end{tabular}

ist Mecca. Due to the regime of specially protected natural areas, it is possible to build structures on the island only in settlements. A solution to the problem was found in the multiple expansion of the territories of settlements, which are built up with tourist centers (the area of settlements is already $10 \%$ of the island's area). In 2017, at the peak of the season, the total number of tourists staying on the island at a time was estimated at 22000-23000 people, while the local population is only 2000 people. To date, the flow of tourists is constrained only by the carrying capacity of the ferry. Opinion polls show that the Baikal and adjacent territories are sacred places for $86 \%$ of the population of the Olkhon; $42 \%$ of the surveyed residents of the Olkhon fear that life will become worse with the development of tourism, since Baikal will become polluted. The willingness to participate in the tourism business among the local population turned out to be lower than expected. As a result, even in the pearl of Lake Baikal, that is, the Olkhon, that is, $48.1 \%$ of the population in no way deal with tourism [48], and half of the population (49\%) would like to change its place of residence [49].

The flow of tourists from China should be talked about separately. Chinese tourism to Siberia is organized in such a way that the profit from tourism bypasses both the BNP and local residents, who are left with garbage, excrement, and degraded nature. Not only the local population of the Olkhon Island, but residents of the Irkutsk oblast and Buryatia are also displeased with mass tourism: $94 \%$ of the respondents express concern about the pollution of Lake Baikal by tourists, $83 \%$ are concerned about the construction of illegal hotels for tourists, $79 \%$ are displeased with an increase in the number of tourists, workers and businessmen from China; $59 \%$ of the respondents believe that the flow of tourists from China must be limited [50]. Polls of residents of Turka, Goryachinsk, and Maksimikha show that the majority does not welcome the development of tourism on Lake Baikal and does not intend to work in this area of business [51]. Residents of Buryatia and the Irkutsk oblast are sure that the ecological situation on Lake Baikal has become worse over the past 5 years and continues to deteriorate [50].

Thus, it can be stated that the criteria for the permissible tourist load are exceeded on the BNT, which causes growing discontent among residents. All this allows us to talk about overtourism in relation to this destination.

\section{THE IMPACT OF TOURISM ON THE LIFE OF THE POPULATION OF BURYATIA: INTERESTS OF THE STATE, LOCAL POPULATION AND BUSINESS}

In general, the number of tourists in Buryatia has increased by $40 \%$ over the past 10 years. In 2018, the republic was visited by more than $1.2 \mathrm{mln}$ people; among them, 400000 people were foreign citizens ${ }^{1}$ [52]. The strategy for the development of domestic and inbound tourism in the Republic of Buryatia for the period up to 2035 involves an increase in the number of tourists accommodated in collective accommodation facilities (CAFs) (sanatoriums, boarding houses, hotels, inns, etc.) to $1.2 \mathrm{mln}$ people [53]. Data on the dynamics of official tourist flows and income from them for 2016-2019 are presented in Table 1 and in Figs. 1 and 2. It can be seen from the table that the number of Russian tourists accommodated in CAFs in Buryatia and income from domestic tourism are steadily growing; the number of foreign tourists accommodated in CAFs and income from inbound tourism are subject to fluctuations. As a rule, the income received from one official foreign tourist is higher than that received from a Russian. However, as

\footnotetext{
${ }^{1}$ The discrepancy between the official data, which reflect the number of tourists accommodated in collective accommodation facilities and the actual number of foreign tourists is explained by the fact that in 2018 Buryatia was officially visited by about 60000 foreign citizens (those who stayed in hotels); however, according to the data of border services, more than 400000 foreign tourists crossed the border through the Kyakhta automobile checkpoint in the same year (https://gazeta-n1.ru/archive/2019/16/74139/).
} 


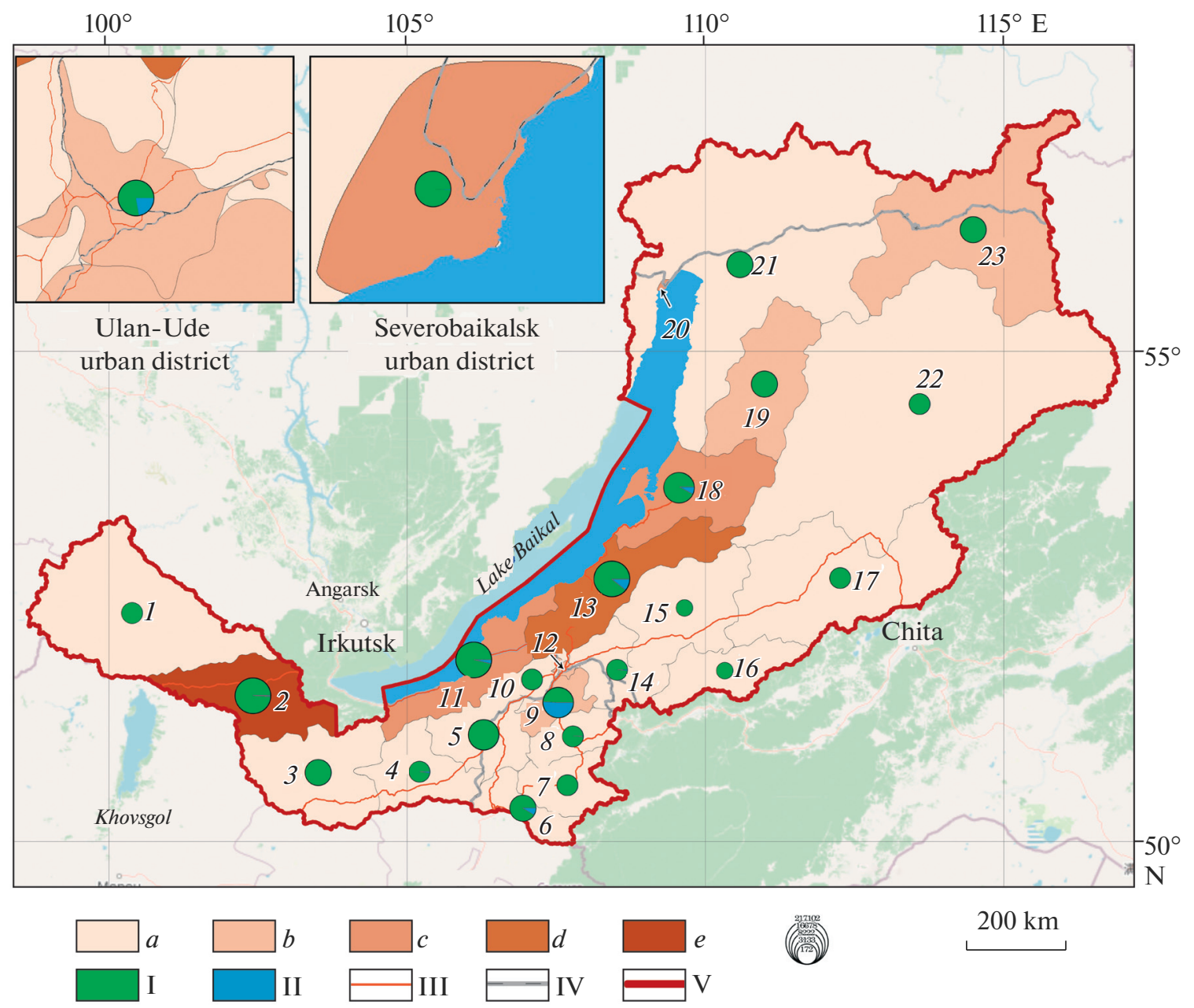

Fig. 1. The distribution of tourist flows by districts of the Republic of Buryatia in 2017. Districts: 1, Okinskii; 2, Tunkinskii; 3, Zakamenskii; 4, Dzhidinskii; 5, Selenginskii; 6, Kyakhtinskii; 7, Bichurskii; 8, Mukhorshibirskii; 9, Tarbagataiskii; 10, Ivolginskii; 11, Kabanskii; 12, Ulan-Ude urban district; 13, Pribaikalskii; 14, Zaigraevskii; 15, Khorinskii; 16, Kizhinginskii; 17, Yeravninskii; 18, Barguzinskii; 19, Kurumkanskii; 20, Severobaikalsk urban district; 21, Severo-Baikalskii; 22, Bauntovskii; 23, Muiskii. Number of tourists per 10000 local residents: $a, 0-3.7 ; b, 3.8-7.4 ; c, 7.5-11.2 ; d, 11.3-14.9 ; e, 15-18.7$. Number of tourists served; person/year: I, citizens of Russia; II, foreign citizens. Roads: III, automobile roads; IV, railways. V, borders of the Republic of Buryatia.

mentioned above, only about $15 \%$ of the total number of all foreign tourists is reflected in the official statistics.

The largest number of organized tourists stayed in hotels in Ulan-Ude (over $80 \%$ of foreign tourists and about $45 \%$ of Russian ones). The main object of interest of tourists in Buryatia (more than half of all excursions) is the Ivolginskii Datsan with the imperishable body of the Hambo Lama Dashi-Dorzho Itigelov being located there. The Pribaikalskii, Kabanskii, Tunkinskii and Barguzinskii regions are the leaders in the number of tourists on the Baikal shore. The average bill of an organized tourist is 2157 rubles/day.

Mongols and Chinese predominate among foreign tourists visiting Buryatia (about 70\%); Europeans make up about $7 \%$. The majority of Russian tourists come to Lake Baikal for personal reasons $(73 \%$, on vacation, $10 \%$, for treatment, and $1 \%$, on pilgrimage tours); business and professional trips make up about $16 \%$ of all visits to Buryatia. Most foreigners come on vacation (about $70 \%$ ), and the number of business trips in this category of tourists does not exceed $6.5 \%$.

Estimates of the economic benefits from the flow of unorganized tourists were carried out using the method of travel costs. The method of travel costs determines the willingness to pay for environmental goods located in a certain place based on information about the time and money spent when visiting this place [58]. As a rule, the value of a recreation facility is determined by the number of visitors per year as a function of visitors' income, price, and a number of socio-economic characteristics. The method is based on surveys and interviews used to find out the expenses that people who make a trip for the purpose of recreation and travel have incurred in order to determine the value of the place. 


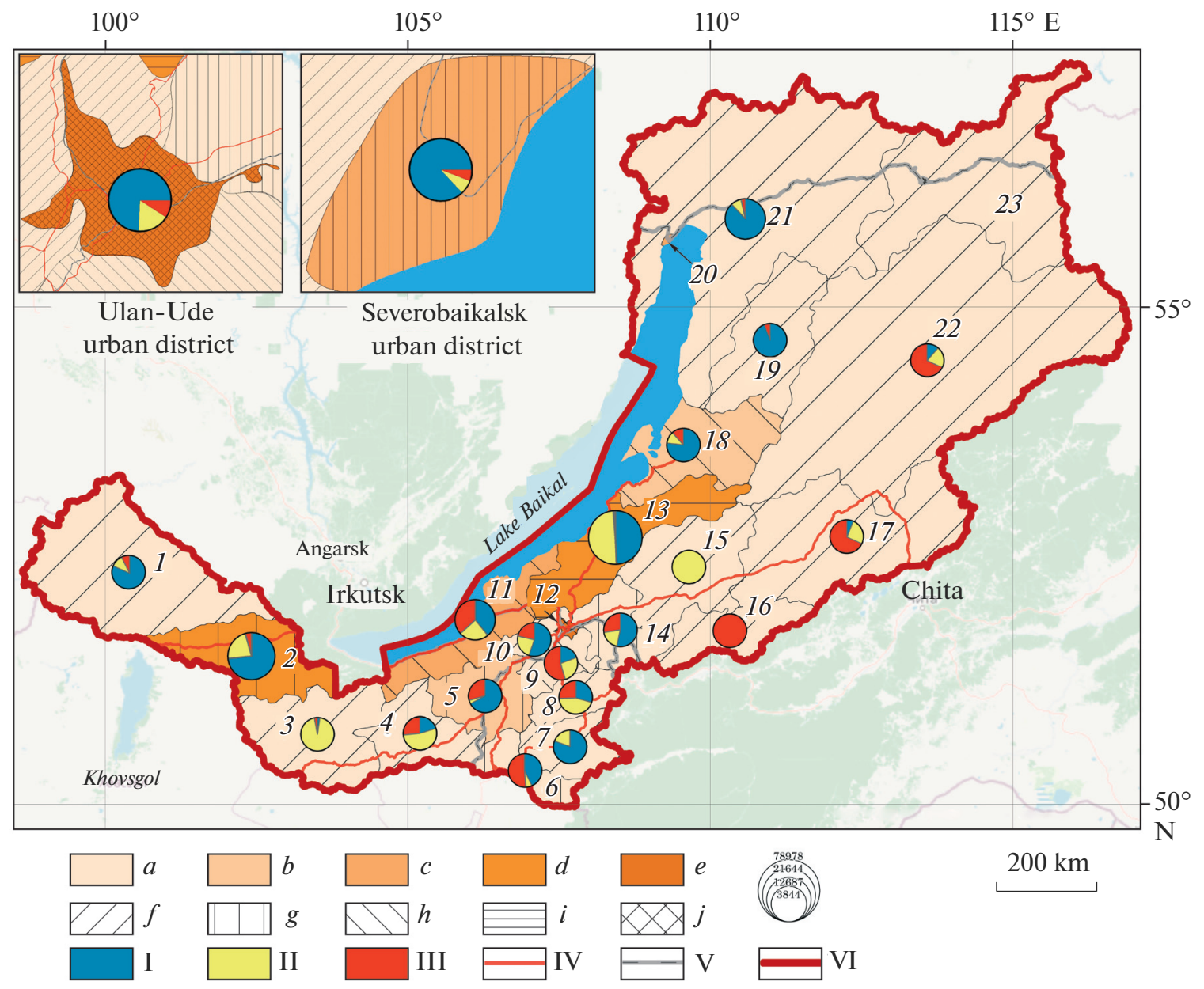

Fig. 2. The distribution of income and tax deductions in the field of tourism by districts of the Republic of Buryatia in 2017. 1-23, see Fig. 1. Income from domestic tourism; thous rubles/year: $a$, 298-21 883; $b, 21884-51857 ; c, 51858-109838$; $d, 109$ 839-306 641; $e, 306642-486$ 933. Income from inbound tourism; thous rubles/year: $f, 0-89 ; g, 90-940 ; h, 941-4861$; and $i, 4862-14$ 734; $j, 14$ 735-169 984. The amount of tax deductions to the budget; thous rubles: I, federal; II, republican; III, local. Roads: IV, automobile roads; V, railways; VI, borders of the Republic of Buryatia.

The main purpose of the interviews conducted in Buryatia in the summer of 2018 was to obtain the information needed to assess the value of the territory using the method of travel costs. Tourists were asked about the duration of their tour to Lake Baikal, the budget of the trip, income in the family and the amount that a tourist is hypothetically ready to spend at certain intervals to preserve Lake Baikal (the socalled willingness to pay). Interviews with tourists showed significant differences in costs depending on which mode of transport was used: a car or an airplane (among the tourists surveyed, there were none that arrived by train). Expenses of tourists visiting the BNT using cars averaged 15000 rubles for a family of two people (costs for gasoline in the amount of $3000-4000$ rubles and for accommodation). This is mainly the population of the cities of the nearest regions, the Irkutsk oblast and the Republic of Buryatia, as well as Mongolia. Tourists visiting the BNT using an airplane spent funds in the range of 60000-
100000 rubles (purchase price of the tour, including the cost of flight, accommodations, and travel).

The frequency of visits to the BNT depends on the place the tourists live. Some tourists from nearby regions indicate their number of visits is more than 100 or 200 times, which indicates regular trips. Tourists visiting the BNT by airplane indicated the number of trips in the range from 1 to 7 times, mostly $1-2$ times. The length of stay on the BNT also depends on the distance of the trip. The interviews showed that tourists from nearby regions indicated the duration of their stay on the shore in the range from 2 to 7 days, mostly 2-4 days. Tourists from remote regions indicate the duration in the range from 3 to 14 days with a predominance of 7 days, i.e., tourists arriving by airplane plan longer trips.

Even if we assume that unorganized tourists spend half the money per day that organized ones do, the shadow income from unorganized tourism in any case 
exceeds the income from organized tourism and amounts to at least 2 bln rubles. Income from the tourist business, both legal and illegal (3.6 bln rubles), is not enough to compensate for the loss of income from economic activities on the BNT. These funds are enough only to receive a monthly income in the amount of the subsistence minimum (in Buryatia in 2018 this is 10858 rubles) for residents of only one Pribaikalskii district of Buryatia. We also note that the largest share in the structure of tax payments related to the tourism sector is accounted for by the federal budget in the Ulan-Ude and Severobaikalsk urban districts as well in a number of regions of Buryatia, i.e., taxes from tourist activities poorly replenish regional and local budgets.

Thus, the flow of tourists to Buryatia is about $1 \mathrm{mln}$ people, of which only $40 \%$ stay in the CAFs and enter the official reporting, while the overwhelming part (about 600000 people) are unorganized tourists. At least, the second budget of the tourism industry remains in the shadows. However, even the aggregate income from tourism is not able to feed the population on the BNT.

In the summer of 2018, more than 15 expert unstructured interviews were conducted within the framework of this study with tourism leaders (two people), leaders of the Trans-Baikal National Park (one), representatives of the tourist business (two), heads of settlements (three), representatives of public environmental organizations (two), local residents (five people) regarding the problems of the BNT, factors of degradation, and the necessary measures for the development of the BNT. The purpose of these interviews was to develop strategies for sustainable ecologically balanced development in the study area.

Based on the foregoing, the following conclusions can be drawn. The tourism business is traditionally looking for new areas to attract organized tourists (shaman tours, the Great Baikal Trail, the development of water tourism, paid parking lots in the TransBaikal National Park, etc.). There is a lack of modern tourist infrastructure to serve tourists and the tourist industry is waiting for help from the state to solve this problem.

The main problem facing the local authorities is the lack of land for the development of settlements due to the special regime of protection and nature management on Lake Baikal. Under these conditions, it is land resources that are the determining factor in the development of the territory. All municipalities have difficulties in providing land plots to privileged categories of the population. The opinion of the local population in matters of territorial zoning was not taken into account. There were no public hearings on the proposed boundaries in all territories under consideration. The question of what to do with the lands that are potentially available for the construction of real estate objects remains open [59].
The second problem is unorganized tourists who do not generate income (unorganized tourists eat their own food, spend the night in their own transport, and do not buy souvenirs), but leave trash and products of their vital activities (for example, tourist buses from Mongolia). The waste is collected by volunteers and schoolchildren, and the costs of removing it are borne by the local population. The lack of toilets for tourists on the shore as well as the construction of comfortable toilets in the case of a large influx of tourists are equally destructive for Baikal. There is no centralized water supply in the shore zone. Water comes from artesian wells or is bought from a water carrier (30 kopecks per bucket). The sewage treatment plants built within the framework of the Baikalskaya Gavan' project do not work (in the Pribaikalskii region, waste is transported to the old treatment plant in Goryachinsk). Removal of a septic tank is quite expensive (1200 rubles per car, which corresponds to prices in the Moscow region). The priority measures to reduce the processes of natural degradation on Lake Baikal are the creation of treatment systems in settlements and tourist centers and the solution of the problem of waste on the shores of Lake Baikal.

The problems faced by the local population are as follows. Fish and fish-breeding factories, sawmills, sanatoriums, and rest houses that functioned during the Soviet period have been closed. The budget places that provide at least a small but guaranteed salary are the most rare. Unemployed people are not registered because unemployment benefits do not cover travel costs to the labor exchange. People stopped regarding work as a priority and switched to subsistence farming. Local residents are dissatisfied with the mass influx of tourists, especially foreign ones, since they almost do not receive any benefits from them and are opposed to foreign business (mainly sawmills and hotels, which are often registered to straw men). However, being forced to somehow survive in the absence of other employment, the locals themselves build guesthouses, unwinding the spiral of overtourism.

In the course of the study, all respondents were asked to additionally assess the main problems, factors of degradation of the BNT and proposals for measures for its development on a 5-point scale (1 is the most important and 5 is the least important). All respondents consider the reduction of forests and littering to be the main problems of the BNT. The main blame for the degradation of the lake is assigned by the majority of the respondents to the regional and federal authorities, which are pursuing inadequate environmental and economic policies. Unorganized tourism was named as the most powerful negative factor affecting Lake Baikal and its shore zone. The following measures are proposed for the development of the BNT: increasing funding for nature conservation, regulating tourism (bringing tourist traffic in line with the maximum permissible loads on natural areas) and restricting foreign business. 
Thus, all respondents noted that the policy of limiting economic activity on the BNT and reliance on mass tourism lead to the degradation of the nature in Baikal and do not solve the problems of financial selfsufficiency of the territory. Under modern economic conditions, the population solves exclusively momentary problems of survival. However, as academician A.K. Tulokhonov rightly noted, a poor man will never be able to protect his living environment [60].

\section{OVERTOURISM: WHAT MUST BE DONE?}

The crises caused by overtourism indicate that tourism is not being developed in many destinations on the principles of sustainability and the tourism industry lacks an understanding of how to achieve it. Many studies have been devoted to the search for ways out of the crisis of overtourism [18, 61, 62]. Researchers are unanimous in the opinion that the policy of restricting the influx of tourists called trexit (English: trexit, that is, from the words tourist and exit), which is currently being carried out by many destinations, is not able to radically solve the problem $[4,23]$. In addition, trexit undermines the economic sustainability of super-tourism destinations and may negatively affect their image in the long term. As an alternative, an integrated approach to the development of territories has been proposed $[4,23,63,64]$, the essence of which is the transformation of the classical model of tourism marketing aimed at a quantitative increase in the number of tourists into a model of organizing tourism activities focused on the qualitative development of the territory. Such a transition requires a high level of management that provides a synthesis of territorial development strategies and tourism development strategies. The tools of this policy are methods of tourism product management (segmentation of demand, demarketing, increasing the contribution of tourism to the regional economy, and improving the organization of tourism).

Overtourism on Lake Baikal arose as a result of errors in the management of the BNT, primarily due to incorrectly chosen development priorities. The high-quality development of the BNT on the principles of sustainability can only be ensured by sustainable or responsible tourism, the most important element of which is the interest of local residents in it. This requires the following: (1) carrying out demarketing of many tourism products (for example, beach tourism, picnic holidays, and ATV rides); (2) focusing on tourism services with high added value; (3) reorienting towards more environmentally friendly types of tourism, which include ecological tourism itself, nature tourism, rural and event tourism, and hiking; (4) developing business tourism focused on an attractive segment of tourists; and (5) revising the policy of attracting foreign tourists.

\section{CONCLUSIONS}

Overtourism is a new challenge that some tourist destinations in Russia have already faced. The concept of BNT development based exclusively on mass tourism has turned out to be flawed. The mass nature of the tourist flow stifles the possibility of full-fledged communication with wild nature, educational, and comfortable recreation provided that the recreational load on the territory is observed. With the existing organization of tourism on Lake Baikal, modern tourist flows are large enough to destroy nature and small enough to become the main source of income for the population. There is a need for a transition to a new paradigm of tourism development, in which the strategies for sustainable development of the territory determine the strategies for marketing/demarketing tourism of the territory and the economic results of tourism development are felt primarily by local residents. This requires a revision of the entire management system of the economic complex.

\section{FUNDING}

The study was carried out by S.N. Bobylev, S.V. Solovyeva, and I.Yu. Khovavko with the financial support of the Russian Foundation for Basic Research (17-29-05078).

\section{REFERENCES}

1. Yakovleva, I.A., Bulatova, V.B., and Kuklina, S.K., The role of ecological tourism in the development of specially protected natural areas and the economy of the region, Fundam. Issled., 2015, no. 11 (5), pp. 10581064.

2. Number of tourist arrivals in Venice 2003-2019. https://www.statista.com/statistics/732406/overnighttourist-arrivals-in-venice-italy/. Cited October 14, 2020.

3. Statistiche demografiche ISTAT. http:demo.istat.it. Cited February 18, 2020.

4. Seraphin, H., Zaman, M., Olver, S., Bourliataux-Lajoinie, S., and Dosquet, F., Destination branding and overtourism, J. Hospitality Tourism Manage., 2019, vol. 38, pp. 1-4.

5. Milano, C., Overtourism and Toutismphobia: Global Trends and Local Context, Barcelona: Ostelea Sch. Tourism Hospitality, 2017.

6. Zhukov, P.V., The influence of overtourism on the tourist market of St. Petersburg, Sovrem. Probl. Servisa Turizma, 2019, vol. 13, no. 4, pp. 132-139.

7. Sanin, A.Yu. and Paranina, T.O., Countering overtourism in the coastal recreational areas of Russian Federation, Sovrem. Probl. Servisa Turizma, 2019, vol. 13, no. 4, pp. 98-111.

8. Jacobsen, J., Iversen, N., and Hem, L., Hotspot crowding and over-tourism: antecedents of destination attractiveness, Ann. Tourism Res., 2019, vol. 76, pp. 53-66.

9. Luque-Gil, A.M., Gomez-Moreno, M.I., and PelaezFernandez, M.A., Starting to enjoy nature in Mediterranean mountains: crowding perception and satisfaction, Tourism Manage., 2018, vol. 25, pp. 83-103. 
10. Mehta, R., Understanding perceived retail crowding: a critical review and research agenda, J. Retailing Consum. Serv., 2013, vol. 20, pp. 642-649.

11. Santana-Jimenez, Y. and Hernandez, J., Estimating the effect of overcrowding on tourist attraction: the case of Canary Islands, Tourism Manage., 2011, vol. 32, pp. 415-425.

12. Prakash, S.L., Perera, P., Newsome, D., Kusuminda, T., and Walker, O., Reasons for visitor dissatisfaction with wildlife tourism experiences at highly visited national parks in Sri Lanka, J. Outdoor Recreation Tourism, 2019, vol. 25, pp. 102-112.

13. Namberger, P., Jackisch, S., Schmude, J., and Karl, M., Overcrowding, overtourism and local level disturbance: How much can Munich handle? Tourism Plann. Dev., 2019, vol. 16 , no. 4, pp. 452-472.

14. Singh, T., Is over-tourism the downside of mass tourism? Tourism Recreation Res., 2018, vol. 43, no. 4, pp. 415-416.

15. Goodwin, H., Overtourism: What is it and how do we address it? Responsible Tourism Partnership. http:// responsibletourismpartnership.org/overtourism. Cited February 18, 2020.

16. Overtourism? Understanding and Managing Urban Tourism Growth beyond Perceptions. Case Studies, Madrid: UN World Tourism Org., 2018.

17. Naumova, I.V. and Savel'ev, I.I., Overtourism: the essence and problem solution, Sovrem. Probl. Servisa Turizma, 2019, vol. 13, no. 4, pp. 27-35.

18. Novichkova, A.V. and Novichkov, N.V., Overtourism: local problems and global solutions, Sovrem. Probl. Servisa Turizma, 2019, vol. 13, no. 4, pp. 36-45.

19. International tourism highlights, World Tourism Organization, 2019. https://www.e-unwto.org/doi/epdf/ 10.18111/9789284421152. Cited March 16, 2020.

20. Peltier, D., Domestic tourists often underestimated in overtourism equation, Skift. https://skift.com/2017/ 12/14/domestic-tourists-often-underestimated-in-overtourism-equation. Cited February 18, 2020.

21. Martin, J.M., Martinez, J.M.G., and Fernandez, J.A.S., An analysis of the factors behind the citizen's attitude of rejection towards tourism in a context of overtourism and economic dependence on this activity, Sustainability, 2018, vol. 10, no. 8, p. 2851.

22. Seraphin, H., Sheeran, P., and Pilato, M., Over-tourism and the fall of Venice as a destination, J. Destination Mark. Manage., 2018, no. 9, pp. 374-376.

23. Koens, K., Postma, A., and Papp, B., Is overtourism overused? Understanding the impact of tourism in a city context, Sustainability, 2018, vol. 10, no. 12, p. 4384.

24. Buckly, J., Florence launches campaign telling tourists how to behave, 2017. https://www.cntraveler.com/story/ florence-launches-campaign-telling-tourists-how-tobehave. Cited February 18, 2020.

25. Leadbeater, C., Anti-tourism protesters in Barcelona slash tyres on sightseeing buses and rental bikes. https://www.telegraph.co.uk/travel/news/bus-attack-inbarcelona-adds-to-fears-tourism-protests-grow. Cited February 18, 2020.

26. Füller, H. and Michel, B., "Stop being a tourist!" New dynamics of urban tourism in Berlin-Kreuzberg, Int. J. Urban Reg. Res., 2014, vol. 38, no. 4, pp. 1304-1318.
27. Coldwell, W., First Venice and Barcelona: now antitourism matches spread across Europe, The Gardian. https://www.theguardian.com/travel/2017/aug/10/antitourism-marches-spread-across-europe-venice-barcelona. Cited February 18, 2020.

28. Colomb, C. and Novy, J., Protest and Resistance in the Tourist City, New York: Routledge. 2016.

29. Novy, J., "Destination" Berlin revisited: from (new) tourism towards a pentagon of mobility and place consumption, Tourism Geogr., 2018, vol. 20, no. 3, pp. 418442.

30. Joppe, M., Tourism policy and governance: Quo vadis? Tourism Manage. Persp., 2018, vol. 25, pp. 201-204. https://doi.org/10.1016/j.tmp.2017.11.011. Cited February $18,2020$.

31. Calzada, I., Local entrepreneurship through a multistakeholders' tourism living lab in the post-violence/peripheral era in the Basque Country, Reg. Sci. Policy Prac., 2019, vol. 11, no. 3, pp. 451-466. https://doi.org/10.1111/rsp3.12130. Cited February 18, 2020.

32. Zerva, K., Palou, S., Blasco, D., and Donaire Benito, J.A., Tourism-philia versus tourism-phobia: residents and destination management organization's publicly expressed tourism perceptions in Barcelona, Tourism Geogr., 2019, vol. 21, no. 2, pp. 306-329.

33. Yazdi, S.K. and Khanalizadeh, B., Tourism demand: a panel data approach, Curr. Iss. Tourism, 2017, vol. 20, no. 8, pp. 787-800.

34. Kantar, T.N.S., Mood of the Nation New Zealanders' perceptions of international visitors. Auckland: Kantar TNS, 2019. https://www.tourismticker.com/wp-content/ uploads/2018/02/Mood-of-the-Nation-Nov-17.pdf. Cited February 18, 2020.

35. Saturation of Tourist Destinations: Report of the Secretary General, Madrid: World Tourism Org., 1981.

36. Aigina, E.V., Overtourism and tourism phobia: new phenomena or old problems? Sovrem. Probl. Servisa Turizma, 2018, vol. 12, no. 4, pp. 41-55.

37. Khovavko I.Yu., Sustainable development: locals know better, EKO, 2018, no. 1, pp. 127-141.

38. Radkau, J., Natur und Macht: Eine Weltgeschichte der Umwelt, Munich: C.H. Beck Verlag, 2000.

39. Vetitnev, A.M. and Chigarev, D.V., Attitude of residents to tourists as an indicator of the problems of overtourism and tourism phobia for tourist destinations (by the example of the resort city of Sochi), Sovrem. Probl. Servisa Turizma, 2019, vol. 13, no. 4, pp. 112-121.

40. Pinke-Sziva, I., Smith, M., Olt, G., and Berezvai, Z., Overtourism and the night-time economy: a case study of Budapest, Int. J. Tourism Cities, 2019, vol. 5, no. 1, pp. $1-16$. https://doi.org/10.1108/IJTC-04-2018-0028. Cited February $18,2020$.

41. Zhang, H. and Xu, H., Impact of destination psychological ownership on residents' "place citizenship behavior," J. Destination Mark. Manage., 2019, vol. 14, pp. 1-14.

42. Lalicic, L., Solastalgia: an application in the overtourism context, Ann. Tourism Res., 2020, vol. 82. https://doi.org/10.1016/j.annals.2019.102766. Cited February $18,2020$. 
43. Gosudarstvennyi doklad "O sostoyanii ozera Baikal $i$ merakh po ego okhrane v 2015 godu" (The State of Lake Baikal and Measures for Its Protection in 2015: State Report), Moscow: Minist. Prir. Resur. Ekol. Ross. Fed., 2016.

44. Evstrop'eva, O.V., Development of the tourist system in the Baikal natural territory, Geogr. Prir. Resur., 2016, no. 5, pp. 184-195.

45. Volchatova, I.V. and Bryukhanova, T.E., The recreational load on the Baikal National Park, XXI Vek. Tekhnosfernaya Bezop., 2016, no. 1 (1), pp. 43-48.

46. Mikheeva, A.S., Maksanova, L.B.-Zh., Abidueva, T.I., and Bardakhanova, T.B., Ecological condition and protection of the Baikal natural territory, Geogr. Prir. Resur., 2016, no. 5, pp. 210-217.

47. Shekhovtsova, T.N., Life quality of the population and the regional strategy for economic development (by example of Olkhon district, Irkutsk oblast), Naukovedenie, 2013, no. 6. http://naukovedenie.ru/PDF/60EVN613.pdf. Cited February 21, 2020.

48. Sidorova, N.V., Socio-ecological problems in the Baikal region: analysis of public opinion of the residents of Olkhon Island, Teor. Prakt. Obshch. Razvit., 2017, no. 11, pp. 29-33.

49. Ivaschenko, T., Siberians believe that they are losing Baikal, Regnum. https://regnum.ru/news/2384752.html. Cited February 18, 2020.

50. Tulokhonov, A.K., A system approach to environmental management in the Baikal region, Geogr. Prir. Resur., 2009, no. 3, pp. 17-22.

51. News from Buryatia and Ulan-Ude in real time, Baikal Daily. https://www.baikal-daily.ru/news/16/362698/. Cited February 18, 2020.

52. Tourism development strategy in Buryatia until 2035. http://docs.cntd.ru/document/561626771. Cited February $18,2020$.

53. Statisticheskii byulleten' no. 05-12-25. Svedeniya o deyatel'nosti organizatsii v sfere turizma Respubliki Buryatiya za 2016 (Statistical Bulletin No. 05-12-25: Information on the Activities of Organizations in the Field of Tourism of the Republic of Buryatia in 2016), Ulan-Ude, 2017.
54. Statisticheskii byulleten' no. 05-12-25. Svedeniya o deyatel'nosti organizatsii $v$ sfere turizma Respubliki Buryatiya za 2017 (Statistical Bulletin No. 05-12-25: Information on the Activities of Organizations in the Field of Tourism of the Republic of Buryatia in 2017), Ulan-Ude, 2018.

55. Statisticheskii byulleten' no. 05-12-25. Svedeniya o deyatel'nosti organizatsii v sfere turizma Respubliki Buryatiya za 2018 (Statistical Bulletin No. 05-12-25: Information on the Activities of Organizations in the Field of Tourism of the Republic of Buryatia in 2018), Ulan-Ude, 2019.

56. Statisticheskii byulleten' no. 05-12-25. Monitoring deyatel'nosti organizatsii v sfere turizma Respubliki Buryatiya (Statistical Bulletin No. 05-12-25: Monitoring the Activities of Organizations in the Field of Tourism in the Republic of Buryatia), Ulan-Ude, 2020.

57. Pearce, D.W., Moran, D., and Biller, D., Handbook of Biodiversity Valuation: A Guide for Policy Makers, Paris: Org. Econ. Coop. Dev., 2002.

58. Dudarova, F., Who sold Baikal. https://novayagazeta. ru/ articles/2020/07/21/86351-kto-prodal-baykal. Cited August 22, 2020.

59. Tulokhonov, A.K., Moe delo skazat' pravdu (I Must Say the Truth), Ulan-Ude: Ekos, 2018.

60. Preobrazhenskii, A.B., Problems of overtourism in modern world and national tourism: solution and overcoming, Sovrem. Probl. Servisa Turizma, 2019, vol. 13, no. 4, pp. 62-73.

61. Yakovleva, S.I., Solutions and prevention of overtourism problem, Sovrem. Probl. Servisa Turizma, 2019, vol. 13, no. 4, pp. 55-61.

62. Sheresheva, M.Yu., Polyanskaya, E.E., and Oborin, M.S., System approach to the development of Russian tourist destinations in conditions of the growing threat of overtourism, Sovrem. Probl. Servisa Turizma, 2019, vol. 13, no. 4, pp. 74-85.

63. Aleksandrova, A.Yu., Overtourism and tourism phobia in European destination cities (Barcelona case), Sovrem. Probl. Servisa Turizma, 2018, vol. 12, no. 4, pp. 56-68.

Translated by L. Solovyova 